\title{
Mapping Sustainable Structural Dimensions for Managing the Brazilian Biodiesel Supply Chain
}

\author{
Silvio Francisco dos Santos', Suzana Borschiver², Vanderléa de Souza ${ }^{3}$
}

\begin{abstract}
It has been widely discussed in Brazil that the production of biodiesel should look for ways for increasing competitiveness considering the balance among economic growth, environmental quality and social well-being through the rational use of resources. The main purpose of this paper is to identify structural dimensions influencing sustainability and competitiveness of the Brazilian biodiesel production chain and, thereby, contribute to the current debate as well as to the process of formulating policy and strategies regarding this important supply chain. As starting point, a number of publications were reviewed allowing the identification of main issues and its combination into relevant factors. Eventually, the factors were put together, resulting in a set of structural dimensions: biodiesel supply chain environment, institutional framework, market conditions, monitoring systems and technological innovation. Then, the structural dimensions were summarized in a conceptual model showing the relationship between them. The structural dimensions may be seen as critical points in which stakeholders would pay attention to ensure successful performance and sustainable competitiveness of the biodiesel production chain. The objective of the entire system is to deliver biodiesel as a clean energy with focus on social inclusion, mitigation of environmental impacts and viability.
\end{abstract}

Keywords: biodiesel; supply chain; sustainability; competitiveness; dimensions; critical factors.

\footnotetext{
'Researcher-Technologist in Metrology and Quality at the Scientific and Industrial Metrology Directorate, Instituto Nacional de Metrologia, Qualidade e Tecnologia (Inmetro), Av. Nossa Senhora das Graças, 50, Duque de Caxias, RJ, ZIP 25250-020, Brazil; School of Chemistry, Universidade Federal do Rio de Janeiro, Rio de Janeiro (UFRJ), Av. Horacio Macedo, 2030, Centro de Tecnologia, Bloco E, ZIP 2194I-909, Cidade Universitária, Rio de Janeiro, RJ, Brazil. E-mail: sfsantos@inmetro.gov.br.

${ }^{2}$ Associated Professor at School of Chemistry, Universidade Federal do Rio de Janeiro (UFRJ), Av. Horacio Macedo, 2030 - Centro de Tecnologia, Bloco E, ZIP: 2 194I-909, Cidade Universitária, Rio de Janeiro, RJ, Brazil. E-mail: suzana@eq.ufrj.br.

${ }^{3}$ Researcher-Technologist in Metrology and Quality at the Scientific and Industrial Metrology Directorate, Instituto Nacional de Metrologia, Qualidade e Tecnologia (Inmetro), Av. Nossa Senhora das Graças, 50, Duque de Caxias, RJ, ZIP 25250-020, Brazil. E-mail:vsouza@inmetro.gov.br
} 


\section{Introduction}

The interest in renewable sources of energy has significantly grown over the last years. Biodiesel is one example of such kind of energy. The importance of biodiesel relies on its possibility to replace petroleum diesel in internal combustion engines, to reduce greenhouse gas emissions (Mofijur, Atabani, Masjuki, Kalam, \& Masum, 20I3; Pieprzyk, Kortlüke, \& Hilje, 2009) as well as to reduce negative impacts on social aspects (Rovere, Pereira, \& Simoes, 2010). Biodiesel production is still dominated by first generation technologies that use mainly biomass food crops as feedstock, however, significant research has been done for development of biodiesel that uses non-food crops (AntizarLadislao \& Turrion-Gomez, 2008; Carriquiry, Du, \& Timilsina, 2010; Dunn, 2005; Florin, Van Ittersum, \& Van De Ven, 20I2; Vasudevan \& Fu, 20I0).

In Brazil, biodiesel contributes to the reduction in imports of mineral diesel and to increase employment generation, since it is able to generate $113 \%$ more jobs and $35 \%$ more of GDP when compared to the mineral diesel (Guilhoto \& Cunha, 20I2). One of the premises of the Brazilian National Biodiesel Production and Use Program is that biodiesel should not be for exclusively commercial purposes: it should help Brazil to develop economically as well as to contribute to environment and society (PNPB, 2004).

Given the strategic importance of the biodiesel to Brazil, it is considered necessary to expand the knowledge on methodologies addressing the peculiarities of its supply chain in order to make it competitive and prepared to comply with requirements on sustainability. Thus, the purpose of this paper is to identify structural dimensions influencing sustainability and competitiveness of the Brazilian biodiesel supply chain and, thereby, contribute to the current debate as well as to the process of formulating policy and strategies for it.

To explore these points, the paper comprises 7 main sections. In section I, the key terms critical success factors, supply chain management and sustainability are outlined. After, in section 2, the methodology of the mapping process is presented, followed by section 3 , in which the delimitation of the study is presented. Section 4 gives a descriptive analysis of the main features of the reviewed publications. Section 5 is the core of the paper. It presents the identified structural dimensions and offers a conceptual model based on them. After, in section 6 , a discussion on the findings will be given, and finally, in section 7 , the paper will be concluded with final comments, and other research process.

\section{Background}

This section provides an overview on the concepts of critical success factors, supply chain management and sustainability forming the background against which the mapping process is conducted.

Rockart (1979) defines critical success factors (CSF) as a limited number of key areas whose satisfactory results ensure the success of an organization and, therefore, such areas should receive continued attention by stakeholders. The CSF method has been applied in many types of organizations, including supply chains (Power, Sohal, \& Rahman, 200 I; Zhou, Huang, \& Zhang, 20II). The process of identifying CSF assesses an organization as a whole and includes social, political and economic aspects.

The concept of supply chain is associated with the issues approached by logistics (Frazelle, 2002; Silva, 2005) and this, in turn, has developed in scope and influence over the years, from workstations to global logistics. A supply chain may be considered as a network of facilities, information systems and other elements connected by suppliers and customers. The logistics activities connect the elements of the chain and, thus, logistics "is what happens in the chain" (Frazelle, 2002). The studies related to supply chain have raised the need for expanding the theory, bringing about the concept of supply chain management (Scramim \& Batalha, 2004).This, in turn, emphasizes the need for integrating operations between producers, distributors, sellers and buyers, through activities such as management of raw materials and products, information, and capital aiming to meet the requirements imposed by the market (Borschiver, 1997; Castro, Lima, \& Cristo, 2002; Teller, Kotzab, \& Grant, 20I I;Villa, 200 I). Supply chain management also emphasizes the importance of establishing strategic relationships between manufacturing companies and their suppliers (Assumpção, 2003).

Significant efforts have been done over the last years to develop methods and metrics for capturing the concept of sustainability (WEF, 2012). The most accepted one may be obtained from the expression sustainable development, as presented by the Brundtland Report, issued by the World Commission on Environment and Development: "sustainable development is development that meets the needs of the present without compromising the ability of future generations meet their own needs" (WCED, 1987). The concept was further elaborated by Agenda $2 \mathrm{I}$, and started to emphasize the principle of integration as one of the basic elements for creating interrelations between social, economic and environmental issues (Nations, 1992). The same principle lead to the concept of "triple bottom line" which states that sustainable businesses depend on the integration of positive inventories of economic, environmental and social resources (Elkington, 1997). 
At this point, it is worth to mention the efforts that have been done to establish a better understanding on the relationship between sustainability and competitiveness. In this regard, the World Economic Forum (WEF) has made progress to integrate both concepts into a new one, which they call sustainable competitiveness. The central idea of the concept is the search for "a development model that would balance economic prosperity, environmental stewardship, and social sustainability" (WEF, 20I2).

Sustainability and supply chain management form the core themes of this paper.The mapping process will consider the theory on CSF to capture key factors and dimensions potentially able to ensure sustainability of the biodiesel supply chain in Brazil. Thus, for the purpose of this paper, it can be conclude that in order to be sustainable the biodiesel supply chain would systematically integrate operations through management of information, raw materials, products and other resources aiming to meet requirements imposed by the market and, at the same time, incorporate goals concern a specific and limited number of factors covering social, economic and environmental issues, taking also into account the context in which the operations happen.

\section{Methodology}

Fink (2010) defines literature review as "a systematic, explicit, and reproducible method for identifying, evaluating, and synthesizing the existing body of completed and recorded work produced by researchers, scholars, and practitioners."In general, the literature review has two main objectives: a) summarize existing research by identifying patterns, themes and research issues, and b) identify concepts related to issues with a view to developing a theory (SEURING \& Müller, 2008). Seuring and Müller point out that the major challenge is the fact that it is not practical conduct the reading of all the documents and, therefore, the analysis of a reduced set of documents related to the themes of research, through a literature review, makes possible address the issues in a systematic way. Thus, given that the enormous amount of information makes the biodiesel production chain complex, dynamic and focus of many discussions, the model adopted here will refer to the following steps (MAYRING, 2000; Seuring \& Müller, 2008): a) Delimitating context of the literature review; b) Searching and selecting publications defining it as basic units of analysis; c) Descriptive analysis, in which formal aspects of publications, such as type and number of publications per year are analyzed; d) Systematic classification of main issues and relevant factors extracted from specialized literature, based on the prospects of $6 \mathrm{Ms}$ perspectives (ISHIKAWA, 1990); e) Selecting categories, in which structural dimensions present in the identified publications are formalized; and f) Assessment of bibliographic material according to structural dimensions allowing discussing and interpreting of results.

\section{Delimitation of the context}

This review is delimited to publications covering the following subjects: biodiesel, sustainability, supply chain management, critical success factors, and their relationships. Although, it is focused on biodiesel production using vegetable oils in Brazil, sometimes will be need to provide comments upon biofuels in general and other kinds of feedstock.

The system boundary of the biodiesel supply chain includes the following main nodes:

- Raw material production: refers to feedstock cultivation and seed harvesting; it includes soil fertilization, watering, oil extraction and transportation of oil seeds for extraction and oil for biodiesel production;

- Biodiesel production: uses of different technology, such as transesterification process, to convert biomass into fatty acid methyl esters (FAME), using an alcohol (ethanol or methanol) as reagent and an alkali (usually $\mathrm{KOH}$ or $\mathrm{NaOH}$ ) as catalyst;

- Biodiesel distribution: biodiesel distribution to fuel stations; and

- $\quad$ Biodiesel use: final use of the biodiesel as BI00 ( $100 \%$ of biodiesel) or blended with fossil diesel as BX (X\% of biodiesel).

The configuration of the biodiesel supply chain may differ depending on the level of vertical integration and the type of feedstock used (Coppead, 2007). For example, in the case of vegetable oils the crushing and processing step may be integrated to cultivation or to the biodiesel production facility. There are also cases in which the cultivation, crushing and processing and biodiesel production are totally integrated. Lastly, there are situations in which there is no vertical integration and the steps are totally separated from each other (Coppead, 2007).

\section{Descriptive analysis of the publications}

The methodology took into account searches for publications on scientific databases such as Scopus and Web of Science. Journals in scientific indexes were preferred, although other non-indexed publications or internal reports from highly reputed organizations such as International Energy Agency (IEA), Energy Information Administration (EIA), World Economic Forum and Organization for Economic Co-operation and Development (OECD) have also been cited.

The sample comprehends 104 publications that were classified into 5 categories compatibles with the theme of the study. It should be observed that some publications are concern to more than one category. Forty eight of the analyzed publications are specifically concerning to biodiesel and bio- 
fuels in general. A set of 12 publications is wider and approach bioenergy system as a whole.A significant amount of the 36 publications concerns to the sustainability and seven publications cover critical success factors subject. Figure I shows the categories and number of publications assigned to them.

The sample covers the period from 1979 to 2013. Most publications are articles from indexed journals (47) and magazines (3). In addition to the articles, the sample comprises 2 I books, 4 conference papers, 4 conference proceedings, 16 reports, 5 standards, 2 thesis and 2 government documents. The majority of the publications are within the period from 2008 to 2013.

\section{Mapping structural dimensions}

This section forms the core of the mapping process. Here, the publications were analyzed in searching for main issues related to the biodiesel supply chain, with focus on the Brazilian chain. The main issues form the basis for defining the relevant factors and these, in turn, are used to define the structural dimensions.

\section{Main issues and relevant factors}

In order to capture the issues and undertake a systematic classification, it was conducted a content analysis of the publications in which the documents were associated to one of the 6 perspectives adapted from 6M approach (Ishikawa, 1990). In this step, the researchers identified underlying categories by means of establishing patterns based upon the relationships between the main issues, resulting in the set

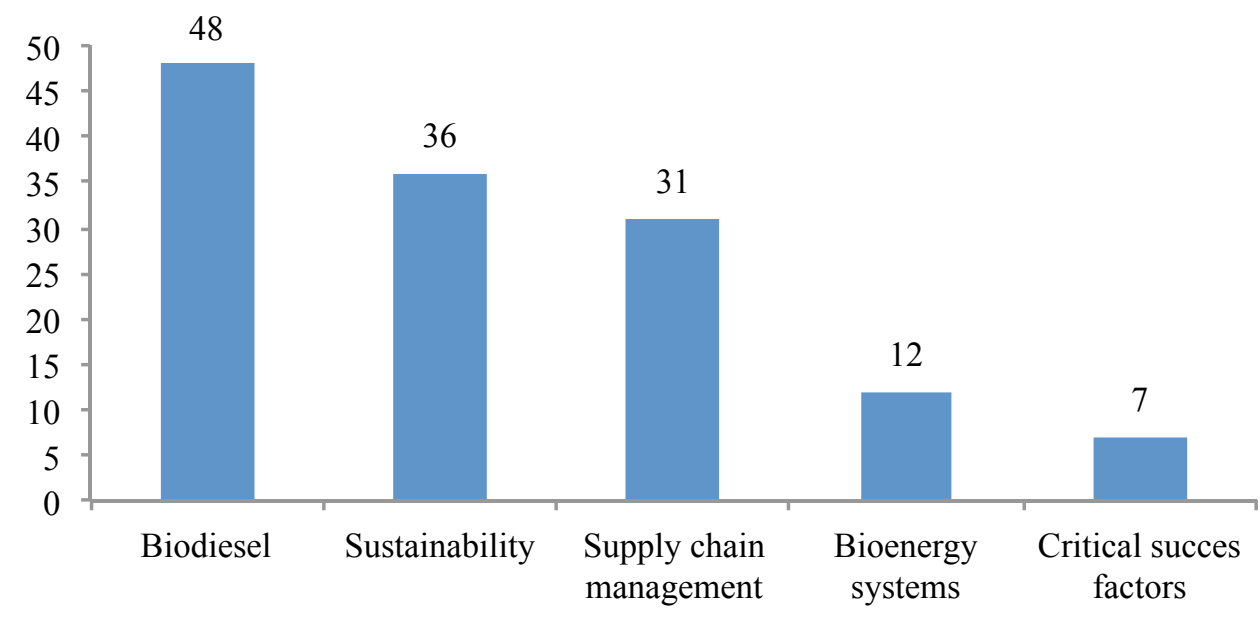

Figure I. Categories of reviewed publications

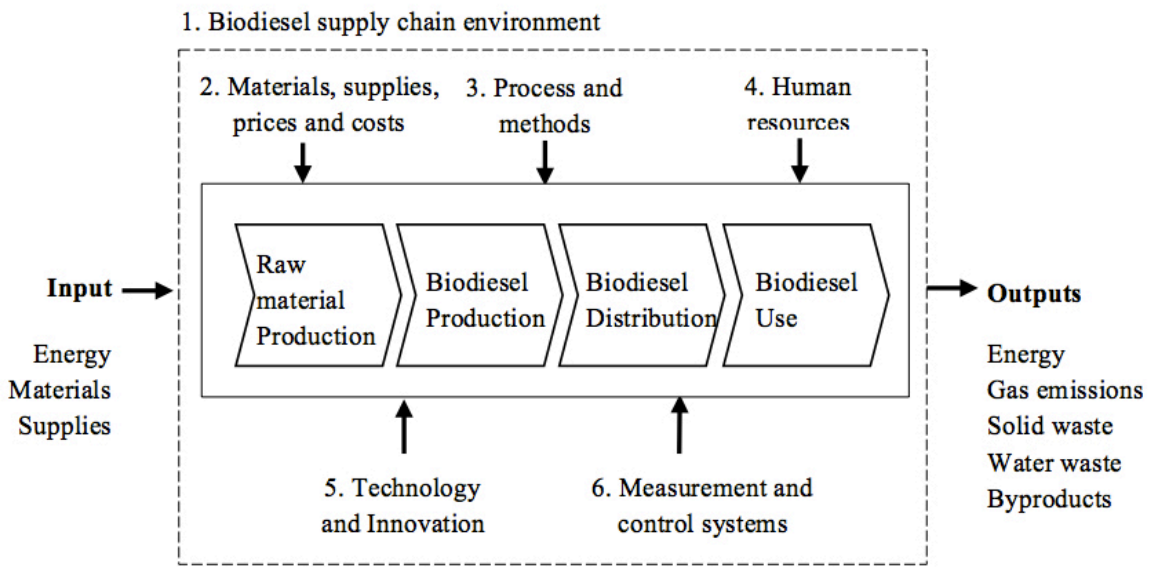

Figure 2. Biodiesel production chain scheme and $6 \mathrm{M}$ perspectives

ISSN: 07 I8-2724. (http://www.jotmi.org) 
of issues shown in Table I.Also, the step occurred through a deductive approach that allows selecting the main issues taking the theoretical basis of the work into consideration (Mayring, 2000). Figure 2 depicts the six adapted perspectives and its relationship with the scheme of the biodiesel supply chain. This approach has provided the insights for capturing the main issues and relevant factors and is mainly an analysis at a high macro level, although also includes issues at a lower operational level when necessary. In addition, it is assumed that the $6 \mathrm{M}$ perspectives cover the main aspects of the majority of organizations and so is suitable for the objectives of the study.

Table I contains the list of selected main issues and relevant factors as well as references from which they were captured. The relevant factors cover the set of main issues captured from the reviewed literature. For example, the relevant factor labeled strategic management comprises seven main issues, being management system scope towards sustainability one of them.

\begin{tabular}{|c|c|c|}
\hline $\begin{array}{l}\text { Relevant } \\
\text { factors }\end{array}$ & Main issues & References \\
\hline \multicolumn{3}{|c|}{ Biodiesel Supply Chain Environment } \\
\hline \multirow[t]{7}{*}{$\begin{array}{l}\text { Strategic } \\
\text { management }\end{array}$} & Management systems scope towards sustainability & $\begin{array}{l}\text { (Gold \& Seuring, 20I I; ISO, 2004b; Janaun \& Ellis, 20I0; } \\
\text { Sarkis, Zhu, \& Lai, 20I I) }\end{array}$ \\
\hline & Needs for integrating biodiesel supply chain & $\begin{array}{l}\text { (McCormick \& Kåberger, 2005; Nations, I 992; Nolin, 20 I0; } \\
\text { Ramaa, Rangaswamy, \& Subramanya, 2009) }\end{array}$ \\
\hline & $\begin{array}{l}\text { Objectives and goals focused on strategic, tactical and } \\
\text { operational level }\end{array}$ & (Ramaa et al., 2009) \\
\hline & $\begin{array}{l}\text { Innovative models and techniques for product and } \\
\text { process }\end{array}$ & $\begin{array}{l}\text { (Buainain \& Batalha, 2007; Coppead, 2007; Seuring, 20I3; } \\
\text { Young, 2009) }\end{array}$ \\
\hline & Policies from different government levels & (Nations, 1992) \\
\hline & Common goals and market-oriented programs & (Chen \& Paulraj, 2004;Villa, 200I) \\
\hline & Emergency management system & (Zhou et al., 20II) \\
\hline \multirow[t]{5}{*}{$\begin{array}{l}\text { Sharing of } \\
\text { Information }\end{array}$} & $\begin{array}{l}\text { Insufficient or missing communication in the supply } \\
\text { chain }\end{array}$ & (Seuring, Sarkis, Müller, \& Rao, 2008) \\
\hline & Needs for structuring and disseminating information & (Remmen, Jensen, \& Frydendal, 2007) \\
\hline & Procedures for internal and external communication & (ISO, 2004b) \\
\hline & Information technology & (Nations, 1992; Nolin, 2010; Young, 2009; Zhou et al., 20II) \\
\hline & Effective use of information technology & (Nolin, 20I0) \\
\hline \multirow{7}{*}{$\begin{array}{l}\text { Coordination } \\
\text { and } \\
\text { Competence }\end{array}$} & $\begin{array}{l}\text { Integration, linkages and sustainability aspects in } \\
\text { decision-making process }\end{array}$ & (Nations, 1992) \\
\hline & $\begin{array}{l}\text { Ability to respond market challenges; supply chain } \\
\text { agility }\end{array}$ & (Aziz \& Zailani, 20I I; IFQC, 2003a, 2003b;Young, 2009) \\
\hline & $\begin{array}{l}\text { Multi-agent coordination problem; collaborative } \\
\text { paradigm }\end{array}$ & (Chen \& Paulraj, 2004;Villa, 200I) \\
\hline & $\begin{array}{l}\text { Cooperation and collaboration efficiency along the } \\
\text { supply chain }\end{array}$ & $\begin{array}{l}\text { (Chen \& Paulraj, 2004; Gold \& Seuring, 20 I I; Ramaa et al., } \\
\text { 2009;Villa, 200I) }\end{array}$ \\
\hline & Motivating teams by implementing performance goal & (Villa, 200I) \\
\hline & $\begin{array}{l}\text { Capabilities to promote technological innovation; } \\
\text { ensuring competence }\end{array}$ & (Assumpção, 2003) \\
\hline & $\begin{array}{l}\text { Partnerships for leadership, competence, innovation } \\
\text { and job creation }\end{array}$ & (ANP, 20I2; McCormick \& Kåberger, 2005) \\
\hline $\begin{array}{l}\text { Infrastructure } \\
\text { and logistics }\end{array}$ & $\begin{array}{l}\text { Needs for transporting products, people, materials, } \\
\text { and equipment }\end{array}$ & (Buainain \& Batalha, 2007; Coppead, 2007; Young, 2009) \\
\hline
\end{tabular}




\begin{tabular}{|c|c|c|}
\hline & $\begin{array}{l}\text { Encouraged use of intermodal solutions; dependency } \\
\text { of road transportation }\end{array}$ & (Young, 2009) \\
\hline & Logistics management for ensuring sustainability & (Coppead, 2007; Gold \& Seuring, 20II) \\
\hline & Effective use of information technology & (Nolin, 20 I0; Ramaa et al., 2009) \\
\hline & $\begin{array}{l}\text { Technological infrastructure, social organization and } \\
\text { logistics }\end{array}$ & (Gold \& Seuring, 201 I; Rovere et al., 2010) \\
\hline \multicolumn{3}{|c|}{ Institutional Framework } \\
\hline \multirow[t]{6}{*}{$\begin{array}{l}\text { Policy on sus- } \\
\text { tainability }\end{array}$} & Mitigating or overcoming environmental impacts & (Gmünder, Singh, Pfister, Adheloya, \& Zah, 20I2; Young, 2009) \\
\hline & Introduce cleaner fuels on the market & (ANP, 20I2; IFQC, 2003a) \\
\hline & $\begin{array}{l}\text { Promoting social inclusion linking energy and social } \\
\text { policies }\end{array}$ & (Guilhoto \& Cunha, 20I2; MME, 20I I; PNPB, 2004) \\
\hline & Government strategies for sustainable innovation & (McCormick \& Kåberger, 2005) \\
\hline & $\begin{array}{l}\text { Set priorities and develop policies on sustainable } \\
\text { development }\end{array}$ & (IFQC, 2003a; Nolin, 20 I0; PNPB, 2004) \\
\hline & Institutional partnerships & (ANP, 20I 2; McCormick \& Kåberger, 2005) \\
\hline \multirow{5}{*}{$\begin{array}{l}\text { Legal and } \\
\text { Regulatory } \\
\text { framework }\end{array}$} & $\begin{array}{l}\text { Voluntary and regulatory initiatives; certification } \\
\text { schemes }\end{array}$ & (Ismail, Rossi, \& Geiger, 20II) \\
\hline & $\begin{array}{l}\text { Adequacy of legislation; policies related to tax incen- } \\
\text { tives and price }\end{array}$ & $\begin{array}{l}\text { (Buainain \& Batalha, 2007; Janaun \& Ellis, 20 I0; Olivério, } \\
\text { 2006) }\end{array}$ \\
\hline & International agreements; overcoming barriers to trade & $\begin{array}{l}\text { (Borschiver, I997; IBF, 2007; Junginger et al., 20I I; Souza, } \\
2010 \text { ) }\end{array}$ \\
\hline & Government guidelines on sustainability & (Coppead, 2007; PNPB, 2004) \\
\hline & Monitoring and enforcement systems & (ANP, 20I2; IFQC, 2003a) \\
\hline \multicolumn{3}{|c|}{ Market Conditions } \\
\hline \multirow[t]{10}{*}{$\begin{array}{l}\text { Market, costs } \\
\text { and prices }\end{array}$} & Conditions impacting on costs & $\begin{array}{l}\text { (Akgul, Shah, \& Papageorgiou, 20I2; Atabani et al., 20I2; } \\
\text { Buainain \& Batalha, 2007; Coppead, 2007; Corsano,Vecchiet- } \\
\text { ti, \& Montagna, 20I I; Demirbas, 2008; IFQC, 2003b; Janaun } \\
\text { \& Ellis, 20 I 0; Khalil, 2006; Mendes \& Costa, 20I0; Olivério, } \\
\text { 2006; Perimenis, Walimwipi, Zinoviev, Müller-Langer, \& Mier- } \\
\text { tus, 20I I; Radich, 2004; Seuring et al., 2008) }\end{array}$ \\
\hline & Technological routes and vertical integration schemes & $\begin{array}{l}\text { (Coppead, 2007; Demirbas, 2008; Reaney, Furtan, \& Loutas, } \\
\text { 2006) }\end{array}$ \\
\hline & Strategic supplier partnership for cost reducing & (Ramaa et al., 2009) \\
\hline & $\begin{array}{l}\text { Impact of prices on competitiveness, market regula- } \\
\text { tion and quality policies }\end{array}$ & (IFQC, 2003b) \\
\hline & Auction mechanism & (MME, 20I3; PNPB, 2004) \\
\hline & Ensure supply and competitive price of biodiesel & (Buainain \& Batalha, 2007; IFQC, 2003b) \\
\hline & Policies related to tax incentives and price & (Buainain \& Batalha, 2007; IFQC, 2003b) \\
\hline & Competitive advantages & $\begin{array}{l}\text { (Aziz \& Zailani, 20I I; Guilhoto \& Cunha, 20I2; Khalil, 2006; } \\
\text { MDIC, 2006) }\end{array}$ \\
\hline & $\begin{array}{l}\text { Ability to respond market challenges; supply chain } \\
\text { agility }\end{array}$ & $\begin{array}{l}\text { (Aziz \& Zailani, 20I I; Kurki, Hill, \& Morris, 20 I0; Pradhan et } \\
\text { al., 2009; Ramaa et al., 2009; Young, 2009) }\end{array}$ \\
\hline & $\begin{array}{l}\text { Make economic use of residues and byproducts (to } \\
\text { offset costs) }\end{array}$ & (Demirbas, 2008; Kurki et al., 20 I0; Pradhan et al., 2009) \\
\hline
\end{tabular}

ISSN: 07 I8-2724. (http://www.jotmi.org) 


\begin{tabular}{|c|c|c|}
\hline \multicolumn{3}{|c|}{ Monitoring Systems } \\
\hline $\begin{array}{l}\text { Performance } \\
\text { measurements }\end{array}$ & $\begin{array}{l}\text { Indirect indicators to assess effectiveness of the tech- } \\
\text { nological innovation }\end{array}$ & (OECD, 1996) \\
\hline & $\begin{array}{l}\text { Measurement systems and peculiarities of innovation } \\
\text { process }\end{array}$ & $\begin{array}{l}\text { (OECD, 1996; Ramaa et al., 2009; Teller et al., 20I I; Zhou et } \\
\text { al., 20II) }\end{array}$ \\
\hline & Innovative methods for measuring performance & (Ramaa et al., 2009) \\
\hline & Mutually accepted models for measuring & $\begin{array}{l}\text { (Assumpção, 2003; Chen \& Paulraj, 2004; Ramaa et al., 2009; } \\
\text { Villa, 200I) }\end{array}$ \\
\hline \multirow{3}{*}{$\begin{array}{l}\text { Monitoring and } \\
\text { Enforcement } \\
\text { systems }\end{array}$} & $\begin{array}{l}\text { Supply chain's critical points and scope impacting on } \\
\text { quality }\end{array}$ & (ANP, 20I2; IFQC, 2003a) \\
\hline & National standards and ability to control fuel quality & $\begin{array}{l}\text { (ANP, 20I2; Brandi, Daroda, \& Souza, 20I I; Souza, 20I0; } \\
\text { IFQC, 2003a) }\end{array}$ \\
\hline & $\begin{array}{l}\text { Monitoring and enforcement systems; quality assur- } \\
\text { ance }\end{array}$ & (ANP, 20I2; IFQC, 2003a) \\
\hline \multirow{3}{*}{$\begin{array}{l}\text { Stakeholder } \\
\text { Perceptions }\end{array}$} & Stakeholder perceptions & (ISO, 2004a, 20I0; Mitchell, Agle, \& Wood, I997) \\
\hline & Satisfaction towards continuous improvement & $\begin{array}{l}\text { (Aziz \& Zailani, 20I I; Ramaa et al., 2009; Seuring \& Müller, } \\
\text { 2008; Teller et al., 20I I; Zhou et al., 20II) }\end{array}$ \\
\hline & $\begin{array}{l}\text { Demands (logistics, technology, systems; integration, } \\
\text { sustainable development, innovation, competitiveness) }\end{array}$ & $\begin{array}{l}\text { (Antizar-Ladislao \& Turrion-Gomez, 2008; Buainain \& Batal- } \\
\text { ha, 2007; Coppead, 2007; Furlan, 2007; Nolin, 2010; Rovere } \\
\text { et al., 2010; Young, 2009) }\end{array}$ \\
\hline \multicolumn{3}{|c|}{ Technological Innovation } \\
\hline \multirow[t]{7}{*}{ Innovation } & $\begin{array}{l}\text { Sustainability and strategies for technological inno- } \\
\text { vation }\end{array}$ & $\begin{array}{l}\text { (Cocco, 2007; Demirbas, 2008; Hall \& Matos, 20I 0; Hall, Ma- } \\
\text { tos, Silvestre, \& Martin, 20I I; Hansen, Olsen, \& Ujang, 20I2; } \\
\text { Khalil, 2006; McCormick \& Kåberger, 2005; Obiero, Birech, } \\
\text { Joyce, Kibet, \& Freyer, 20I3) }\end{array}$ \\
\hline & Innovative methods for sustainability & (Lal, 2007; Tang \& Zhao, 2009) \\
\hline & Developing technological innovations & $\begin{array}{l}\text { (Antizar-Ladislao \& Turrion-Gomez, 2008; Atabani et al., } \\
\text { 20I2; Carriquiry et al., 20I 0; Demirbas, 2008; Furlan, 2007; } \\
\text { Gold \& Seuring, 20I I; Hall \& Matos, 20I0; Hall et al., 20I I; } \\
\text { Nolin, 20I0; Rovere et al., 20I 0;Vasudevan \& Fu, 20I0) }\end{array}$ \\
\hline & New sources for producing biodiesel & $\begin{array}{l}\text { (Amaral, 2009; Atabani et al., 20I 2; Bonin \& Lal, 20I2; } \\
\text { Coppead, 2007; Demirbas, 2008; Dunn, 2005; Embrapa, 2007; } \\
\text { McCormick \& Kåberger, 2005; Nunes, 2007; Olivério, 2006; } \\
\text { Ramos, 2008, 2009; Vasudevan \& Fu, 20I0) }\end{array}$ \\
\hline & Conditions for innovation and competitiveness & $\begin{array}{l}\text { (Coppead, 2007; Junginger et al., 20I I; MME, 20I3; PNPB, } \\
\text { 2004;Young, 2009) }\end{array}$ \\
\hline & Alternative farming systems & $\begin{array}{l}\text { (Achten et al., 20I 0; Buainain \& Batalha, 2007; Khalil, 2006; } \\
\text { Lal, 2007; Obiero et al., 20I3) }\end{array}$ \\
\hline & $\begin{array}{l}\text { Make economic use of residues and byproducts (im- } \\
\text { prove technology) }\end{array}$ & $\begin{array}{l}\text { (Antizar-Ladislao \& Turrion-Gomez, 2008; Cocco, 2007; } \\
\text { Coppead, 2007; Demirbas, 2008; Hansen et al., 20 I2; Kurki } \\
\text { et al., 20I0; Pradhan et al., 2009; Young, 2009) }\end{array}$ \\
\hline
\end{tabular}

Table I. Structural dimensions, relevant factors and main issues affecting the Brazilian biodiesel chain

ISSN: 07 I8-2724. (http://www.jotmi.org)

Journal of Technology Management \& Innovation (c) Universidad Alberto Hurtado, Facultad de Economía y Negocios. 


\section{Identification of structural dimensions}

The whole process for identifying structural dimensions happened deductively and inductively and was related to the mentioned theory taken as background (Mayring, 2000; Seuring \& Müller, 2008). In the inductive method, the II relevant factors (Table I) were developed after analyzing the main issues and considering the context of the biodiesel production chain. Building upon these results, the II factors were summarized into five structural dimensions influencing the biodiesel supply chain: biodiesel supply chain environment, institutional framework, market conditions, monitoring systems and technological innovation. The process leads to a conceptual model based on the structural dimensions and factors identified in the mapping process (Figure 3 ). The conceptual model shows the structural dimensions and their relationship, specified according to the concepts that constitute the theoretical basis of this paper as well as the specificities of the Brazilian biodiesel chain. The structural dimensions interact to reach the main goal of the system: to produce sustainable and competitive cleaner energy (biodiesel) with focus on social inclusion, mitigation of environmental impacts and economic viability.

The structural dimensions may be seen as critical points in which stakeholders would pay attention to ensure successful performance of the biodiesel chain. Here, stakeholder is defined as "any group or individual who can affect or is affected by achievement of the organization's objectives" (Mitchell et al., 1997). The conceptual model coupled with the structural dimensions form the basis for discussing the results.

\section{Discussion}

The purpose of this section is to evaluate and interpret the five structural dimensions mainly through an overview of the relevant factors that originated them. The analysis begins suggesting that the main goal of the system is to promote biodiesel as a clean energy. In this context, the entire system should be able to provide conditions to deliver biodiesel to the stakeholders and to promote sustainable competitiveness.

\section{Biodiesel supply chain environment}

The biodiesel supply chain environment is the structural dimension that concerns to the flows in the entire supply chain, and to the interactions of individual companies with other companies and with other elements in the chain. It covers the following relevant factors: strategic management, sharing of information, coordination and competence, and infrastructure and logistics. The biodiesel supply chain environment may be affected by the quality of operations and strategies from the overall supply chain and from individual companies levels. In both cases, the quality of the entire chain is strongly related to the extent in which the structural dimensions interact.

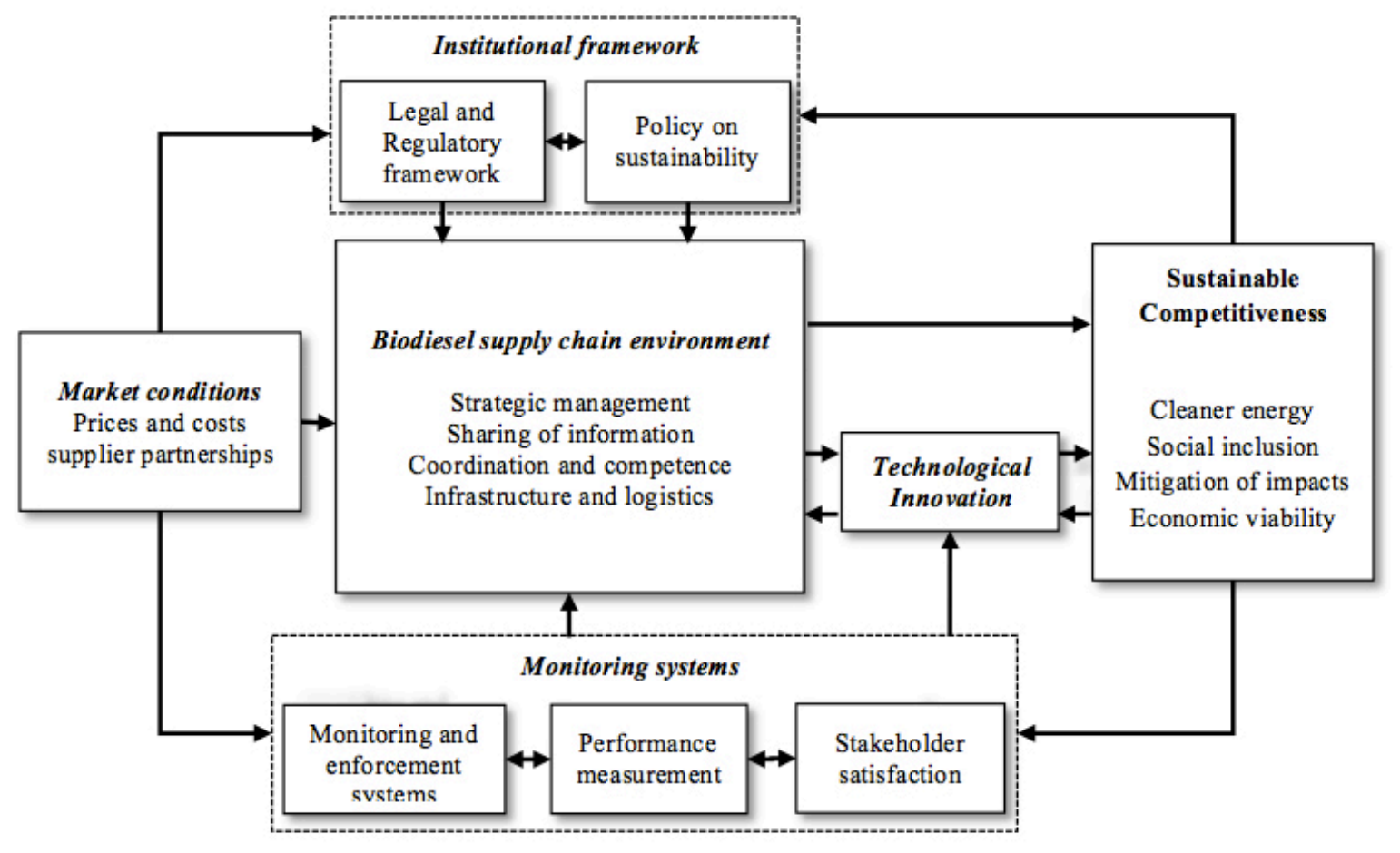

Figure 3. Sustainable competitiveness of the Brazilian biodiesel chain

ISSN: 07 I 8-2724. (http://www.jotmi.org)

Journal of Technology Management \& Innovation (c) Universidad Alberto Hurtado, Facultad de Economía y Negocios. 
In order to manage the flows in a supply chain it is necessary the presence of managers operating in strategic parts of the chain.Villa (200I) calls these managers "agents" of the chain. In general, the agents are distributed in different companies, have limited communication and local autonomy.Villa (200I) points out that this configuration coupled with the natural competition among agents leads to the biggest problem of the management of supply chains: the multi-agent coordination. This paradigm has been subject of debate in strategic management theory in which some authors emphasize the concept of collaborative advantage (Chen \& Paulraj, 2004) in opposition of competitive advantage (Porter, 1989). In the context of collaborative advantage, a network is a composition of interdependent relationships designed through strategic collaboration with a set of common goals, aiming common benefits (Chen \& Paulraj, 2004). In this respect, common goals would be pursued through an efficient allocation of resources, market-oriented programs, motivation of teams towards performance goal as strategies to overcome the collaborative paradigm (Villa, 200I).

Along the same lines, Assumpção (2003) proposed the development of the supply integration in order address common goals such as sustainable development. The author suggested the development of new capabilities as a mean for promoting technological innovations in products and processes.An example of this approach is the Brazilian Monitoring Program Fuel Quality (PMQC). This program is based on partnerships with research institutions, universities and Brazilian states and has contributed to the creation of technical competence and generation of new knowledge in the field of fuels and biofuels (ANP, 20I2). This example shows the importance of institutional partnerships, not only for building competence, but also to create leadership to develop innovation in process and products, and to generate employment and new business. These findings are confirmed by the literature, which point out institutional relationships as a key factor of bioenergy systems (McCormick \& Kåberger, 2005).

Bringing the Agenda $2 \mathrm{I}$ guidelines to the context of the biodiesel supply chain, a possible action to reach integration would be exchange experience between organizations from all nodes of the supply chain. A key challenge in doing so is the difficult to connect concepts such as information and information society to the concept of sustainable development (Nolin, 2010).Although sharing of information at every node of the supply chain is difficult to implement (Ramaa et al., 2009) it seems this is one of the few ways to establish the framework in which the integration takes place. In this regard, Ramaa et al (2009) have suggested that through the use of performance management systems, organizations can manage the achievement of its objectives and goals focused on strategic, tactical and operational level and also increase supply chain collaboration efficiency. In order to reach these goals identifying relevant stakeholders' perceptions is highly recommended (ISO, 2004a, 20I0). Building on the insights provided by Agenda 2 I (Nations, 1992), Nolin (2010) highlighted that information gathering and sharing are needed to help policymakers set priorities and develop policies. Nolin argues that information technology can be used to support communicative aspects of integration, especially in the sustainable energy sector, since facilitates integration of sustainability aspects and contributes to the strengthening of the sustainable development.

The use of information technology is of great importance to define a framework for dealing with events that can produce extensive damage, that is, an emergency management system (EMS). This kind of system helps to identify and respond to potential emergencies and potential accidents that can impact on the environment. It provides technological resources to the establishment of procedures for internal and external communication concerning relevant environmental aspects (ISO, 2004b; Zhou et al., 20 I I).

Infrastructure and logistics remain as great concerns of the Brazilian biodiesel chain. In order to address them, innovative solutions will be required to operate the needs for transporting products, people, materials, and equipment (Buainain \& Batalha, 2007; Coppead, 2007; Young, 2009). Information technology can play an important role in this regard but it is still necessary eliminating bottlenecks such as the almost entire dependency of the use of road transportation. In order to deals with this problem, it would be encouraged to make a better use of intermodal solutions such as waterways, railways and pipelines (Young, 2009). Gold and Seuring (201 I) presented a review addressing logistics issues and confirmed the high relevance of logistics management for ensuring implementation of the sustainability aspects on bioenergy systems and, thus, proposed the establishment of instruments for improving production systems, taking into account all supply chain's stakeholders, collaboration, and the interlinkage of sustainability, strategic management and social network (Gold \& Seuring, 20 I I; McCormick \& Kåberger, 2005).

\section{Institutional framework}

The institutional framework determines the environment in which the elements of the biodiesel supply chain interact to produce biodiesel in a sustainable and competitive manner. It covers two relevant factors: legal and regulatory framework, and policy on sustainability. In the institutional context, the process for defining policy and incentives play an important role. The energy policy may include policy on taxation rates, energy costs, international agreements (Borschiver, 1997), adequacy of legislation (Olivério, 2006), barriers to trade (Brandi et al., 20I I; IBF, 2007; Junginger et al., 20I I; Souza, 2010). Incentives can be offered by the government in order 
to develop and maintain the supply chain sustainability and competitiveness. It can be applied to improve water management, and conservation practices (Janaun \& Ellis, 2010) and also to compensate financial advantages (Buainain \& Batalha, 2007; Janaun \& Ellis, 20I0).

In defining institutional policy, laws and regulation it is necessary to pay attention to sustainability aspects. For example, in the process of choosing which oilseed to produce, the main criterion to be used would be the potential of oilseed depending on geographic region and climate since these conditions impact directly on sustainability aspects (Khalil, 2006; Mourad, 2008; PNPB, 2004). In Brazil, palm oil and babassu palm are more appropriate for North region while cultivation of rapeseed, sunflower and cotton is more favorable in the South region. Soybean can be cultivated in almost all region, excepting Northeast (Khalil, 2006). Each of these regions has different social, environmental and economic needs that have to be considered by policy makers.

In this direction, the Brazilian government has established an important program called National Program for Production and Use of Biodiesel (PNPB) that has the following main goals: a) to establish a sustainable program for promoting social inclusion; b) to ensure competitive prices, quality and supply; and c) to produce biodiesel from different oil sources and in different regions. The importance of the PNPB in the sustainability context relies on the Brazilian intention of establishing a linkage between an energy policy and a social policy. In this respect, the Social Seal Certification Program is a Brazilian initiative taking part of the PNPB. It certifies the biodiesel producers that buy 10-30\% of their feedstock from family farmers. According to the PNPB, at least in theory, only biodiesel producers with the Social Seal Certification could sell biodiesel in the Brazilian market. The national market is supposed to be opened only if biodiesel producers were unable to meet the Brazilian demand with certified biodiesel (PNPB, 2004).

The quality and applicability of the policy, laws and regulations has a strong influence on the sustainability and competitiveness of the chain as well as on market conditions. Indeed, the role of institutional framework goes beyond these elements. Government attitudes towards the efficiency of the biodiesel supply chain activities are also determinant, since excessive bureaucracy, overregulation and inability to provide appropriated services for the sector may impose additional costs and slow its sustainable development (WEF, 20I2). The attitudes of companies from the biodiesel supply chain in applying sustainable practices are also crucial. In general, decision-making process does not consider the specificities of the chain and does not properly create linkages between the three sustainability aspects although many government and voluntary initiatives, including legal and regulatory frameworks, scorecards, voluntary standards and certification schemes have been done (Ismail et al., 20II).

\section{Market conditions}

An acceptable level of stability of the market conditions is important for the overall performance of the biodiesel supply chain. The chain cannot be sustainable and competitive unless the market conditions are stable. In the Brazilian case, the creation of conditions for the consolidation of the sector is still in process and takes into account goals concerning social inclusion and reduction of regional disparities. The commercialization of biodiesel is made through public auctions in which trading volume, suppliers and price conditions are known. The auction set a reference price and the winning companies are those that offer biodiesel at the lowest price and meet the quality criteria required by the Brazilian regulatory agency. To ensure the participation of family farming, at least $80 \%$ of the trading volume shall be from producers holding the Social Fuel Seal (MME, 20II). Currently, 17 of the 60 plants hold the Social Fuel Seal.They are responsible for an authorized capacity of $6.549 \times 103$ m3/year (MME, 20I3).

Regarding to the development of international trade, high fossil fuel prices, import tariffs and mitigation policies are the most important barriers to the commercialization of biodiesel worldwide. Thus, reducing import tariffs and developing multinational agreements, including standardization and provisions of sustainability requirements, would overcome some of these barriers (Junginger et al., 20l I). In this context, metrology plays an important role as the basis of the standardization process since it provides reference standards (including certified reference materials) that serve to evaluate whether some characteristics and related specifications meet a desirable level of quality (Brandi et al., 20l I). Standardization may be viewed from two perspectives: national standards coupled with regulations and conformity assessment procedures are essential to quality assurance processes and to promote national competitiveness, therefore, they may also serve as unnecessary barriers to worldwide trade. With respect to incentives strategies, Buainain and Batalha (2007) argue that high cost of producing biodiesel compared to the petroleum diesel requires the use of tax incentives and observe the that, in Germany, the largest producer of biodiesel in the world, the product competitiveness in relation to petroleum diesel is highly based on incentives.

The production of biodiesel depends on several conditions such as methods of producing and types of raw materials used in the process. The feedstock is the largest single component of the costs (Demirbas, 2008; Olivério, 2006; Perimenis et al., 20II; Radich, 2004) representing more than $75 \%$ of the overall biodiesel production cost (Atabani et al., 
2012). Crude glycerin' is a byproduct that has economic value and so helps to offset the cost of biodiesel production since it can be used in the production of soap and pharmaceutical products (Demirbas, 2008). The costs of producing biodiesel also vary depending on the level of vertical integration of the processes of crushing and processing (Demirbas, 2008; Reaney et al., 2006) and the technological route adopted (Demirbas, 2008). In general, the more integrated, the lower the cost of production. However, the decision of integration must take into consideration the investment required to do so (Coppead, 2007). The ethyl route generates more costs than the methyl route regardless of the level of vertical integration (Coppead, 2007; Demirbas, 2008). Cost of land and cost of labor also contribute to the competitiveness of the biodiesel as a renewable fuel (Khalil, 2006; Mendes \& Costa, 2010).

Reducing raw materials costs (Akgul et al., 2012; Olivério, 2006; Radich, 2004) and biodiesel production costs (Akgul et al., 2012; Buainain \& Batalha, 2007; Corsano et al., 20I I; Khalil, 2006; Perimenis et al., 20I I; Radich, 2004) are important aspects concerning market conditions. Tax incentives and pricing are mechanisms for facilitating the penetration of cleaner fuels on the market (IFQC, 2003b). Manage all these aspects, along with capital, operating costs and logistic costs, is a complex task that have a great effect on the overall cost of producing biodiesel and, consequently, on the market conditions.

\section{Monitoring systems}

Monitoring systems covers performance measurements, monitoring and enforcement systems, and stakeholder satisfaction issues. In order to be efficient and well-functioning the biodiesel supply chain should be able to allocate and make use of resources in their most productive uses. Also, it should assure that biodiesel is produced and commercialized according to required specifications. The use of innovative methods for monitoring and enforcement systems (IFQC, 2003a) as well as for measuring performance systems is of great importance. It should consider not only financial data but also measures based on process such as quality, flexibility, speed, customer service level (Ramaa et al., 2009) and stakeholder satisfaction.

Performance measurement may be defined as a system that provides a mutually accepted model of goals, indicators, methods of measuring, and specifies procedures, responsibilities and mode of governance (Ramaa et al., 2009). It enables people focus on what is important to the company (Ramaa et al., 2009; Teller et al., 20I I; Zhou et al., 20l I) and allows introducing continuous improvement of the organization's reputation. Performance measurement system also involves the use of indicators on research, development and inno- vation. In order to address measurement and monitoring needs, Life Cycle Assessment (LCA) can be useful in identifying opportunities to improve performance at various points of the product's life cycle as well as in selecting of relevant indicators for measuring environmental performance (Remmen et al., 2007). LCA is the most complete and applied tool in biodiesel supply chain literature, although in most of the cases it is mainly used to deals with environmental and economic issues (Bonin \& Lal, 20I2; Cocco, 20I I; ISO, 2006a, 2006b; Manik, Leahy, \& Halog, 2013; Seuring, 20I3; Wang, Calderon, \& Lu, 20II).

Monitoring and enforcement systems help to fully implement quality assurance procedures (IFQC, 2003a). This kind of system depends on standardization and the ability to control fuel quality at the point of distribution (IFQC, 2003a). In the Brazilian case, the focus of the model is on physical and chemical properties of the biodiesel rather than raw materials or biodiesel production and distribution processes (Araújo, 2005; Lobo, Ferreira, \& Cruz, 2009).

A comprehensive monitoring system contributes to the effectiveness of the regulation of environmental and economic aspects related to fuel markets, since it promotes environmental compliance by the strict supervision of the fulfillment of all specifications and minimizes fuel tax evasion that leads to anticompetitive market practices (ANP, 20I2).

\section{Technological innovation}

Technological innovation, either in relation to products, process or management techniques, is the main foundation of sustainable competiveness. Improvement of technology should be economic beneficial, should look for mitigating or overcoming environmental impacts (Gmünder et al., 20I2), diversification of raw materials (Dunn, 2005), better use of supplies and byproducts, and should contribute to development and creation of jobs (Young, 2009).

Innovation can emerge from management practices, stakeholder satisfaction and perceptions as well as from results of monitoring, performance systems and other different sources depending on economic factors, such as costs and demand, personnel skills and knowledge, institutional framework, and the ability of the companies to appropriate gains from their innovation (OECD, 2005). It also depends on the types of external linkages that a company in the biodiesel chain is able to maintain. These linkages can be identified as open information sources, acquisition of knowledge and

\footnotetext{
I The term "glycerin" applies to the purified commercial products normally containing $>95 \%$ of glycerol. The term "glycerol" applies only to the pure chemical compound I,2,3-propanetriol (Gnothe \& Gerpen, 2005)
} 
technology and innovation co-operation with other companies or public research institutions (OECD, 2005).

Improvement of technology potentially comprehends all products and process from the biodiesel supply chain that aim an improved environmental and social quality at least on the level of the guidelines provided by recognized standards. It also includes technical aspects related to logistics as well as technologies, such as fat extracting from residues (Coppead, 2007). In this regard, a well-established institutional framework and the support of public and private sector are drivers to the innovative activity. The presence of high-quality scientific institutions generating basic knowledge through extensive collaboration in research and technological development is also crucial for building new technologies (WEF, 20I2).

Many studies emphasize the need of deploying sustainable technologies to carry out operations of the biodiesel supply chain (Furlan, 2007; Gold \& Seuring, 20I I) and development of technological innovations to address the biodiesel sustainability demands (Furlan, 2007; Nolin, 20 I0; Rovere et al., 2010). In general, these studies refer to: a) minimization of emissions impacting on the atmosphere (Furlan, 2007; IPCC, 20I I; Mofijur et al., 20 I3; Pieprzyk et al., 2009; Walker et al., $2010)$; b) reduction of generation of waste and water consume; c) increasing the level of mechanization (Khalil, 2006; Young, 2009); d) improvement of production and distribution processes (Coppead, 2007; Olivério, 2006; Silva, 2005), e) development of the supply chain's ability to provide valueadded byproducts (Demirbas, 2008; Kurki et al., 2010; Pradhan et al., 2009), and f) development of new sources of oil (Coppead, 2007; Demirbas, 2008; Vasudevan \& Fu, 2010).

The development of technological innovation in addressing social issues is still under debate, although some investigations have been done. Hall and Matos (Hall \& Matos, 20l0; Hall et al., 20l I) argue that innovation is able to solve some technological and commercial issues, but has also potential to create additional social problems, such as increasing in social exclusion due to greater mechanization. On the other hand, McCormick and Kåberger draw attention to the fact that technological innovation is often exclusively related to the development, diffusion, and use of new technologies. They emphasize the need for distinguishing between technological, organizational and social innovation mainly when defining strategies for sustainable development (McCormick \& Kåberger, 2005).

Regarding to alternatives for farming systems, researchers have drawn attention to the need for introducing improvement in processes for managing soil and water resources, enhancement of the biodiversity (Khalil, 2006; Lal, 2007) and increasing of agricultural productivity (Khalil, 2006; Lal,
2007; Obiero et al., 20/3). In this regard, it is emphasized that optimizing fertilization, agronomic practices and genetics are the major system improvement options (Achten et al., 2010; Buainain \& Batalha, 2007). The use of new sources of oil would require developing new technology to harvest, process and convert plant material into biodiesel. Industrial biotechnology has been used to produce enzymes and microorganisms to yield value-added chemicals from renewable sources (Tang \& Zhao, 2009).

Statistics on technological innovation are difficult to measure (OECD, 1996), limited and give an incomplete pattern of technological change in industry (OECD, 1996). Therefore, in the absence of direct measures, statistics on patents broadly use indirect indicators of the effectiveness of the innovation process. Since patent statistics is a source of information on invention and diffusion of technology and innovation, and encompass legal, technical, and economic aspects, researchers on technological innovation recommend they must be interpreted carefully (OECD, 1996). There are about 600 identified technological innovations related to biofuels in the world, including statistics on biodiesel. The main advances involve raw materials transformation, processing of oils by transesterification, and obtaining of liquid carbonaceous fuels (Cepal, 20II).

\section{Conclusions}

This study has taken an extensive review of the literature encompassing management and sustainability aspects of the biodiesel supply chain and issues surrounding these concepts with focus on the Brazilian chain and its specificities.

Based on the literature review and available knowledge regarding the Brazilian supply chain the study offers a conceptual model which comprises the integration of 5 structural dimensions, II relevant factors and 62 main issues as shown in Table I and Figure 3. The main objective of the system is to deliver biodiesel as a clean energy. In order to reach this goal, the conceptual model considers the need for balancing sustainability and competitiveness goals, with both concepts embodied in a new one called sustainable competitiveness (WEF, 2012). The primary focus of the system is on social inclusion, mitigation of environmental impacts and economic viability. The market conditions interact directly with the biodiesel supply chain environment affecting the way in which prices, production, raw material, operational and other costs, and supplier partnerships are managed. It also provides inputs for the institutional framework where laws, regulations and policy governing the biodiesel market are the defined. The interrelation with monitoring system provides conditions for the production and commercialization of biodiesel looking for overall competitiveness of the chain. Within the biodiesel environment the companies interact to implement 
their strategies, carry out their operations and manage the flows of the elements of the chain. In doing so, information technology, coordination of agents, available infrastructure and logistics play a crucial role. As any kind of system, the entire chain is affected by market conditions and the institutional framework. Its performance, operations and quality are monitored by systems specially designed. Technological innovation is of great importance to the system since it is the main foundation of sustainable competitiveness.

This approach must be seen as a process of expanding the knowledge about the context in which the biodiesel production happens, considering the needs for sustainability and competitiveness. The framework presented here is only a step towards what Weick (1995) calls theorizing process. It should be emphasized that the results are most dependent upon the various assumptions made by the researchers along the entire process. Given the complexity of the Brazilian biodiesel chain, a number of different underlying dimensions may be found, depending on the consideration of a series of factors such as methodology applied and perspectives or concepts used by researchers. Certainly, the set of dimensions found is not definitive and further investigation should consider this and also that the model is strongly context dependent.

\section{Acknowledgments}

Silvio F. Santos thanks Prof. Humberto S. Brandi, Director of Scientific and Industrial Metrology Directorate from National Institute of Metrology, Quality and Technology (Inmetro, Brazil), for his support and helpful discussions.

\section{References}

ACHTEN, W.M.J., J.Almeida, V. Fobelets, et al. (20I0). Life cycle assessment of Jatropha biodiesel as transportation fuel in rural India. Applied Energy, 87(I2), 3652-3660.

AKGUL, O., N. Shah, L.G. Papageorgiou. (20I2). Economic optimisation of a UK advanced biofuel supply chain. Biomass and Bioenergy, $4 \mathrm{I}(0)$, 57-72.

AMARAL, D.F. (2009). Panorama do mercado de extração de óleos. Paper presented at the I Simpósio Tecnológico PBIO de Extração de Óleos Vegetais, Rio de Janeiro.

ANP. (20I2). O programa de monitoramento da qualidade dos combustíveis - PMQC (Vol. 5). Rio de Janeiro: Agência Nacional do Petróleo, Gás Natural e Biocombustíveis - ANP (Brasil).
ANTIZAR-LADISLAO, B., J.L. Turrion-Gomez. (2008). Second-generation biofuels and local bioenergy systems. Biofuels, Bioproducts and Biorefining, 2(5), 455-469. doi: 10.1002/bbb. 97

ARAÚJO, R.M. (2005). Controle de qualidade de biodiesel. Rio de Janeiro: Agência Nacional do Petróleo, Gás Natural e Biocombustiveis (ANP) Retrieved from http://www.mme. gov.br/programas/biodiesel.

ASSUMPÇÃO, M.R.P. (2003). Reflexão para a gestão tecnológica em cadeias de suprimento. Gestão \& Produção, I0(n.3), 345-36I.

ATABANI, A.E., A.S. Silitonga, I.A. Badruddin, et al. (20I2). A comprehensive review on biodiesel as an alternative energy resource and its characteristics. Renewable and Sustainable Energy Reviews, I6(4), 2070-2093.

AZIZ, A.K.A., S. Zailani. (20I I). A conceptual paper on determinants and outcomes of supply chain agility. Paper presented at the International Conference on Computer Communication and Management, Singapura. http://www.ipcsit. com/vol5/83-ICCCM20I I-C040.pdf

BONIN, C., R. Lal. (20I2). Bioethanol potentials and lifecycle assessments of biofuel feedstocks. Critical Reviews in Plant Sciences, 3I (4), 27I-289.

BORSCHIVER, S. (1997). Análise técnica, econômica e de tendências da indústria de aditivos para alimentos no Brasil. (Master), Universidade Federal do Rio de Janeiro (UFRJ), Rio de Janeiro.

BRANDI, H.S., R.J.Daroda,T.L. Souza. (20I I). Standardization: an important tool in transforming biofuels into a commodity. Clean Technologies and Environmental Policy, I3(5), 3.

BUAINAIN, A.M., M.O. Batalha. (2007). Cadeia produtiva da agroenergia (Vol. 3). Brasilia: IICA: MAPA/SPA; I I 2p.

CARRIQUIRY, M.A., X. Du, G.R. Timilsina. (20I0). Secondgeneration biofuels (D.R.G.E.a.E.Team, Trans.) (Pp. 57p):The World Bank.

CASTRO, A.M.G., S.M.V. Lima, C.M.P.N. Cristo. (2002). Cadeia produtiva: marco conceitual para apoiar a prospecção tecnológica. Paper presented at the Simpósio de Gestão da Inovação Tecnológica, Salvador.

CEPAL. (20II).Análisis comparativo de patentes en la cadena de producción de biocombustibles entre América Latina y el resto del mundo (pp. 43p.). Santiago, Chile: Comisión Económica para América Latina y el Caribe (Cepal). 
CHEN, I.J., A. Paulraj. (2004). Towards a theory of supply chain management: the constructs and measurements. Journal of Operations Management, 22(2), II9-150.

COCCO, D. (2007). Comparative study on energy sustainability of biofuel production chains. Proceedings of the Institution of Mechanical Engineers, Part A: Journal of Power and Energy, 22 I (5), 637-645.

COCCO, D. (20I I). Life-cycle assessment of bioenergy production systems from oilseed rape crops. Proceedings of the Institution of Mechanical Engineers, Part A: Journal of Power and Energy, 225(I), 63-73.

COPPEAD. (2007). Planejamento estratégico tecnológico e logístico para o Programa Nacional de Biodiesel (Vol. I): Instituto Brasileiro de Petróleo, Gás e Biocombustíveis (IBP).

CORSANO, G., A.R. Vecchietti, J.M. Montagna. (20I I). Optimal design for sustainable bioethanol supply chain considering detailed plant performance model. Chemical Engineering, 35(8), 1384-1398.

DEMIRBAS, A. (2008). Biodiesel: a realistic fuel alternative for diesel engines. London: Springer-Verlag London Limited. DUNN, R.O. (2005). Other alternative diesel fuels. In G.G. Knothe, J.V.; Krahl, J. (Ed.), The Biodiesel Handbook (pp. 232286). Champaign:AOCS Press.

ELKINGTON, J. (1997). Cannibals with forks: the triple bottom line of 2 Ist century business. Oxford: Capstone Publishing Ltd.

EMBRAPA. (2007). Cultivo de canola. Sistemas de Produção, 3(Nov/2007). http://sistemasdeproducao.cnptia.embrapa.br

FINK, A. (2010). Conducting research literature reviews: from paper to the internet (I. Sage Publications Ed. 3rd ed. Vol. I). USA: Sage Publications, Inc.

FLORIN, M.J., M.K. Van Ittersum, G.W.J. Van De Ven. (2012). Selecting the sharpest tools to explore the foodfeed-fuel debate: Sustainability assessment of family farmers producing food, feed and fuel in Brazil. Ecological Indicators, 20, 108-120.

FRAZELLE, E. (2002). Supply chain strategy: the logistics of supply chain management: McGraw-Hill.

FURLAN, L.T. (2007, 21/09/2007). Opportunities and challenges: innovation in renewable energies in Brazil. Paper presented at the OECD, Berlin.
GMÜNDER, S., R. Singh, S. Pfister, et al. (20I2). Environmental impacts of Jatropha curcas biodiesel in India. Journal of Biomedicine and Biotechnology, 2012.

GNOTHE, G., J.V. Gerpen. (2005). Biodiesel production: basics of the transesterification reaction The Biodiesel Handbook (pp. 34-49). Champaign:AOCS Press.

GOLD, S., S. Seuring. (20I I). Supply chain and logistics issues of bio-energy production. Journal of Cleaner Production, 19(I), 32-42.

GUILHOTO, J., M. Cunha. (20I2, October 20I2). Socioeconomic impacts of biodiesel industry in Brazil. Paper presented at the Biodieselbr International Conference 2012, Sao Paulo, Brazil.

HALL, J., S. Matos. (20 I0). Incorporating impoverished communities in sustainable supply chains. International Journal of Physical Distribution and Logistics Management, 40(I-2), 124-147.

HALL, J., S. Matos, B. Silvestre, et al. (20I I). Managing technological and social uncertainties of innovation: the evolution of Brazilian energy and agriculture. Technological Forecasting and Social Change, 78(7), I I47-I I 57.

HANSEN, S.B., S.I. Olsen, Z. Ujang. (20I2). Greenhouse gas reductions through enhanced use of residues in the life cycle of Malaysian palm oil derived biodiesel. Bioresource Technology, 104, 358-366.

IBF. (2007). White paper on internationally compatible biofuel standards, Tripartite Task Force Brazil, European Union and United States of America. In BRASIL/UE/EUA (Ed.), International Biofuels Forum (IBF) (Pp. 95p.).

IFQC. (2003a). Monitoring and enforcement of fuel quality Fuel quality strategies training manual (Pp. 36). Sydney, Australia: International Fuel Quality Center (IFQC).

IFQC. (2003b). Pricing and market regulation issues which influence the success of fuel quality changes Fuel quality strategies training manual (pp. 32). Sydney, Australia: Fuel Quality Center (IFQC).

IPCC. (20II). Special report on renewable energy sources (SRREN) (F. Plenary, Trans.). In IPCC (Ed.), IPCC (pp. 26).Abu Dhabi, Emirados Árabes Unidos: Intergovernmental Panel on Climate Change (IPCC).

ISHIKAWA, K. (1990). Introduction to quality control. 
ISMAIL, M., A. Rossi, N. Geiger. (201I). A compilation of bioenergy sustainability initiatives Retrieved from http://www.fao.org/bioenergy/28l90-0l db4fcd5 I560954e6| 7923620b75c5e7.pdf

ISO. (2004a). ABNT NBR 1600I: responsabilidade social sistema da gestão. Requisito ABNT (pp. 12p). Rio de Janeiro: Associação Brasileira de Normas Técnicas (ABNT).

ISO. (2004b). ABNT NBR ISO I400I - Sistemas da gestão ambiental. Requisitos com orientações para uso ABNT (pp. 27p). Rio de Janeiro: Associação Brasileira de Normas Técnicas (ABNT).

ISO. (2006a). ISO I4040:2006 - Environmental management - Life cycle assessment - Principles and framework.

ISO. (2006b). ISO I4044:2006 - Environmental management - Life cycle assessment - Requirements and guidelines.

ISO. (20I0). ABNT NBR ISO 26000 - Diretrizes sobre responsabilidade social ABNT (pp. 122). Rio de Janeiro: Associação Brasileira de Normas Técnicas (ABNT).

JANAUN, J., N. Ellis. (2010). Perspectives on biodiesel as a sustainable fuel. Renewable and Sustainable Energy Reviews, 14(4), I312-1320.

JUNGINGER, M., J. Van Dam, S. Zarrilli, et al. (20II). Opportunities and barriers for international bioenergy trade. Energy Policy, 39(4), 2028-2042.

KHALIL, C.N. (2006). As tecnologias de produção do biodiesel. In MDIC-STI/IEL (Ed.), O Futuro da Indústria: Biodiesel (Vol.v. I4, pp. 83-90). Brasília: MDIC-STI/IEL.

KURKI, A., A. Hill, M. Morris. (2010). Biodiesel: the sustainability dimensions. National Sustainable Agriculture Information Service (ATTRA), 12p.

LAL, R. (2007). Soil science and the carbon civilization. Soil Science Society of America Journal, 7 I (5), I 425- 437.

LOBO, I.P., S.L.C. Ferreira, R.S. Cruz. (2009). Biodiesel: parâmetros de qualidade e métodos analíticos. Química Nova, v. 32, 1596-1608.

MANIK, Y., J. Leahy, A. Halog. (20I3). Social life cycle assessment of palm oil biodiesel: a case study in Jambi Province of Indonesia. International Journal of Life Cycle Assessment, I-7.
MAYRING, P. (2000). Qualitative Content Analysis (Vol. I).

MCCORMICK, K., T. Kåberger. (2005). Exploring a pioneering bioenergy system:The case of Enköping in Sweden. Journal of Cleaner Production, I3(I0-II), I003-1014.

MDIC (Ed.). (2006). O futuro da indústria: biodiesel. Coletânea de artigos (Vol. I4). Brasília: MDIC-STI/IEL.

MENDES, A.P.D.A., R.C.D. Costa. (2010). Mercado brasileiro de biodiesel e perspectivas futuras. In BNDES (Ed.), BNDES Setorial (Vol. 3I, pp. 253-280): Banco Nacional de Desenvolvimento Econômico e Social.

MITCHELL, R.K., B.R. Agle, D.J.Wood. (1997). Toward a theory of stakeholder indentification and salience: defining the principle of who and what really counts. Academy of Management Review, 22(4), 33.

MME. (20II). Biocombustíveis: instrumento para inclusão social e fator de desenvolvimento econômico com respeito ao meio ambiente. Brasília: Ministério das Minas e Energia (MME) Retrieved from http://www.mme.gov.br/mme/galerias/arquivos/Artigos/Biocombustxveis_instrumento_para_ inclusxo_social.pdf.

MME. (20I3). Boletim Mensal dos Combustíveis Renováveis - Ago/2013 (D.d.C.R. (DCR), Trans.) Boletim Mensal dos Combustiveis Renováveis (67 ed.). Brasilia: Ministério das Minas e Energia, Secretaria de Petróleo, Gás Natural e Combustíveis Renováveis.

MOFIJUR, M.,A.E.Atabani, H.H. Masjuki, et al. (20I3).A study on the effects of promising edible and non-edible biodiesel feedstocks on engine performance and emissions production: A comparative evaluation. Renewable and Sustainable Energy Reviews, 23, 39I-404.

MOURAD,A.L. (2008).Avaliação da cadeia produtiva de biodiesel obtido a partir da soja. (Doutorado), Universidade Estadual de Campinas (Unicamp), Campina/SP. Retrieved from http://www.bibliotecadigital.unicamp.br/document/?code=vt Is $000445752 \& f d=y$

NATIONS, U. (1992). Agenda 2I: Integrating environment \& development in decision-making (D.o.E.a.S. Affairs, Trans.) The United Nations Conference on Environment and Development (UNCED). Rio de Janeiro: The United Nations - UN.

NOLIN, J. (2010). Sustainable information and information science. Information Research, I5(2), 43 Ip. 
NUNES, S.P. (2007). Produção e consumo de óleos vegetais no Brasil. Conjuntura Agrícola, (159), I0p. http://www.deser.org.br/documentos/doc/Produ\%C3\%A7\%C3\%A30\%20 e\%20consumo\%20de\%20\%C3\%B3leos\%20vegetais.pdf

OBIERO, C.O., R. Birech, J. Joyce, et al. (20I3). Performance of jatropha (Jatropha curcas L.) under different soil and climatic conditions in Kenya. Asian Journal of Agricultural Research, $7(I), 43-50$.

OECD. (1996). Innovation, patents and technological strategies. Paris, France: OECD.

OECD. (2005). Oslo Manual: Guidelines for collecting and interpreting innovation data. The measurement of scientific and technological activities. (3rd ed.): European Commission.

OLIVÉRIO,J.L. (2006). O programa brasileiro de biodiesel na visão da indústria de equipamentos. In MDIC-STI/IEL (Ed.), O futuro da indústria: biodiesel. Coletânea de artigos (Vol.v. I4, pp. 105-125). Brasília: MDIC-STI/IEL.

PERIMENIS, A., H. Walimwipi, S. Zinoviev, et al. (201 I). Development of a decision support tool for the assessment of biofuels. Energy Policy, 39(3), I782-1793.

PIEPRZYK, B., N. Kortlüke, P.R. Hilje. (2009). The impact of fossil fuels. Greenhouse gas emissions, environmental consequences and socio-economic effects (pp. 98p): Energy Research Architecture (ERA).

PNPB. (2004). Portal do Biodiesel. Prograna Nacional de Produção e Uso do Biodiesel (PNPB), (16/02/20I I). http:// www.biodiesel.gov.br/

PORTER, M.E. (1989). Vantagem competitiva: criando e sustentando um desempenho superior. Rio de Janeiro: Campus.

POWER, D.J., A.S. Sohal, S.-U. Rahman. (200I). Critical success factors in agile supply chain management - An empirical study. International Journal of Physical Distribution and Logistics Management, 3 I (4), 247-265.

PRADHAN, A., D.S. Shrestha, A. Mcaloon, et al. (2009). Energy life-cycle assessment of soybean biodiesel (pp. 25p): United States Department of Agriculture (USDA).

RADICH, A. (2004). Biodiesel performance, costs, and use. Modeling and Analysis Papers. http://www.eia.doe.gov/oiaf/ analysispaper/biodiesel/index.html

RAMAA, A., T.M. Rangaswamy, K.N. Subramanya. (2009). A review of literature on performance measurement of supply chain network. Paper presented at the Second International
Conference on Emerging Trends in Engineering and Technology, India. http://www.computer.org/portal/web/csdl/ doi/I0.I I09/ICETET.2009.18

RAMOS, L.P. (2008). Microalgas. BIODIESELBR, 72p.

RAMOS, L.P. (2009). Biodieseis não convencionais. BIODIESELBR, 49.

REANEY, M.J.T., W.H. Furtan, P. Loutas. (2006). A critical cost benefit analysis of oilseed biodiesel in Canada (Biocap, Trans.) (pp. 34): University of Saskatchewan.

REMMEN,A.,A.A.Jensen, J. Frydendal. (2007). Life cycle management - a business guide to sustainability. Paris.

ROCKART, J.F. (1979). Chief executives define their own data needs. Harvard Business Review(57), 8I-93.

ROVERE, E.L.L., A.S. Pereira, A.F. Simoes. (2010). Biofuels ans sustainable energy development in Brazil. World Development, 39(6), 10.

SARKIS, J., Q. Zhu, K.-H. Lai. (20I I). An organizational theoretic review of green supply chain management literature. International Journal of Production Economics, I30(I), I-I5.

SCRAMIM, F.C.L., M.O. Batalha. (2004). Método para análise de benefícios em cadeias de suprimento: um estudo de caso. Gestão \& Produção, I I (3), 33 I-342.

SEURING, S. (20I3). A review of modeling approaches for sustainable supply chain management. Decision Support Systems, 54(4), I513-1520.

SEURING, S., M. Müller. (2008). From a literature review to a conceptual framework for sustainable supply chain management. Journal of Cleaner Production, I6(15), 1699-1710.

SEURING, S., J. Sarkis, M. Müller, et al. (2008). Sustainability and supply chain management - An introduction to the special issue. Journal of Cleaner Production, I6(I5), I545-I55I. doi: http://dx.doi.org/10.1016/j.jclepro.2008.02.002

SILVA, L.C. (2005). Agronegócio: logística e organização de cadeias produtivas. Paper presented at the II Semana Acadêmica de Engenharia Agrícola, Rio de Janeiro. http:// www.agais.com/manuscript/ms0107_agronegocio.pdf

SOUZA, V. (2010). Biofuels: the Brazilian experience. Paper presented at the INMETRO, África.

TANG,W.L., H. Zhao. (2009). Industrial biotechnology:Tools and applications. Biotechnology Journal, 4(I2), I725-I 739. 
TELLER, C., H. Kotzab, D.B. Grant. (20II). Improving the execution of supply chain management in organizations. International Journal of Production Economics, In Press, Corrected Proof.

VASUDEVAN, P., B. Fu. (20I0). Environmentally sustainable biofuels: advances in biodiesel research. Waste and Biomass Valorization, I(I), 47-63.

VILLA, A. (200I). Introducing some supply chain management problems. International Journal of Production Economics, 73(I), I-4.

WALKER,T.H., P. Cardellichio, A. Colnes, et al. (20I0). Massachusetts biomass sustainability and carbon policy study. $\ln \mathrm{T}$. Walker (Ed.), (pp. 182p). Brunswick, Maine: Manomet Center for Conservation Sciences.

WANG, Z., M.M. Calderon,Y.Lu. (20I I). Lifecycle assessment of the economic, environmental and energy performance of Jatropha curcas L. biodiesel in China. Biomass and Bioenergy, 35(7), 2893-2902.

WCED. (1987). Our Common Future: Report of the World Commission on Environment and Development (W.C.o.E.a. Development, Trans.). In W.C.o.E.a. Development (Ed.), UN. Genebra:The United Nations - UN.

WEF. (20I2). The Global Competitiveness Report 201220I3. In K. Schwab (Ed.), (20I2-20I3 ed., pp. 545). Geneva: World Economic Forum.

WEICK, K.E. (1995). What theory is not, theorizing is. Administrative Science Quartely(40), 6.

YOUNG, E. (2009). Sustainable Brazil. Brazil's perspectives in the agricultural undustry (Vol. 5, pp. 25): Ernest \& Young.

ZHOU, Q., W. Huang, Y. Zhang. (20II). Identifying critical success factors in emergency management using a fuzzy Dematel method. Safety Science, 49(2), 243-252. 